\title{
The Gregory Thesis Visits the Tropics*
}

\author{
Peter Warr \\ Australian National University
}

January 2006

\begin{abstract}
A concern about large, export-oriented projects relates to the flows of foreign exchange into the domestic economy that they produce. These flows occur both during the investment phase of the project and subsequently during its operational phase, through export earnings. Foreign exchange inflows produce direct benefits for some groups, but may also indirectly harm others, through an appreciation of the real exchange rate. These indirect outcomes, known as the 'Gregory effect' in Australia and as the 'Dutch disease' or 'booming sector' effect elsewhere, are studied in this paper in the context of a large infrastructure project in Laos.
\end{abstract}

JEL classification: F32, O11, O53

\footnotetext{
${ }^{*}$ Paper presented to a conference in honour of Bob Gregory, Canberra, 16 June, 2005. Helpful comments of two anonymous referees, a suggestion from Helen Hughes, discussions with Prema-chandra Athukorala, Max Corden and George Fane, and the outstanding research assistance of Arief Yusuf, Arief Ramayandi and Arriya Mungsunti are all gratefully acknowledged. The author accepts responsibility for what remains.
} 


\section{Introduction}

When very large infrastructure projects are undertaken in small economies, they can be expected to have large effects. There may be significant improvements in domestic incomes and sometimes in government revenues, but in many cases these gains are achieved at the expense of some adverse effects. These may include undesired environmental consequences and social disruption caused by the displacement of people formerly residing on the project site. When large increases in government revenue are involved, pressure will be placed on the quality of governance, with corruption and misappropriation of funds a constant danger. Not least, there may be unintended macroeconomic effects. Not surprisingly, these projects are always controversial.

\section{A Large Export-oriented Project in Laos}

The government of the Lao People’s Democratic Republic (Lao PDR, subsequently Laos, for brevity) has agreed with a consortium of international institutions and private investors to undertake a major investment project on the Nam Theun River. The project, called Nam Theun 2 (subsequently NT2) ${ }^{1}$, will absorb a heavy investment in construction of a dam and hydroelectric generating capacity and will subsequently generate large foreign exchange earnings from the sale of electricity to neighboring Thailand. ${ }^{2}$ The size of the total investment package is around US\$ 1.03 billion, extending from 2004 to 2009, equivalent to roughly two thirds of the current level of Laos’ annual GDP. Obviously, it is a large project and it is indeed controversial. ${ }^{3}$ This study focuses on the project's macroeconomic effects and their implications for poverty within Laos.

\footnotetext{
${ }^{1}$ A smaller dam was earlier constructed on the Nam Theun River and it is now known as Nam Theun 1.

${ }^{2}$ Thailand will purchase $95 \%$ of the electricity produced. The other $5 \%$ is for sale within Laos.

${ }^{3}$ Appendix A lists 27 of the large number of web sites either devoted to the Nam Theun 2 project (most attacking it) or with substantial coverage of it.
} 
The financing of the NT2 project will be overwhelmingly foreign, coming from both international institutions (30\% of the total), including both the World Bank and the Asian Development Bank, and private investors (the remaining 70\%). Although the foreign exchange cost of the project is large, the effect on Laos is limited by the fact that most of the material inputs will be imported and most of the human input will also be foreign - engineers, machinery operators and managers. Large foreign exchange inflows have macroeconomic effects that are now relatively well understood. Central to these is the appreciation of real exchange rates - an increase in non-traded goods prices relative to traded goods prices within the domestic economy, implying reduced competitiveness of traded goods industries, both export-oriented and import-competing, relative to goods and services which are not traded internationally. These effects are often referred to as the 'Dutch disease', named after the effects on the Dutch economy of increased exports of gas from the North Sea, beginning in the 1960s. In Australia, it is widely known as the 'Gregory thesis', after Gregory (1976), one of the most influential economic studies to be published in Australia.

\section{The Gregory Thesis}

The economic analysis underlying this effect is summarized in Figure 1, which draws upon Salter (1959), Gregory (1976), Snape (1977) and Corden (1981). For convenience, we assume a single consumer. Suppose the initial equilibrium is at point $\mathrm{A}$, where the market for non-tradables clears, as it must, since non-tradables can be obtained only by producing them domestically. At A, the market for tradables also clears, implying that the current account is exactly in balance since production of tradables exactly matches their consumption. At this point, the price of non-traded goods relative to traded goods - the inverse of the real exchange rate - is given by the slope of the production possibility frontier at A and also the slope of the indifference curve $U_{0}$ tangential to $\mathrm{A}, P_{\mathrm{A}}$. 
The project, or booming sector, is characterized as an increment to the foreign exchange earning capacity of the domestic economy. It does not directly affect production possibilities elsewhere in the economy, implying that the project or booming sector uses few if any resources shared by other sectors. These features are represented by a vertical shift in the production possibility frontier from $\mathrm{TN}$ to $\mathrm{T}^{\prime} \mathrm{N}^{\prime}$. Now consider point $\mathrm{B}$, lying vertically above A. By construction, the slope of the production possibility frontier $\mathrm{T}^{\prime} \mathrm{N}^{\prime}$ at $\mathrm{B}, P_{B}$, is the same as $P_{A}$. But point B is not an equilibrium, in the diagram as shown, because the valuation placed by the consumer on non-tradables relative to tradables - the slope of the indifference curve $U_{1}$ passing through $\mathrm{B}$ - exceeds $P_{B}$.

The consumer has a higher real income at B than at A. At this higher real income and at the relative prices $P_{B}$ she desires to consume more non-tradables as well as more tradables than at A, and not merely more tradables, as would be the case at B. Point B would be an equilibrium if and only if the expenditure elasticity of demand for non-tradables was zero. Provided non-tradables are a normal good, she attempts to substitute non-tradables for tradables, moving in a southeast direction from B. In doing so, she bids up the price of nontradables because more non-tradables will be produced only at a higher relative price. Suppose the new equilibrium is at C, lying on the highest attainable indifference curve, $U_{2}$. At this point, the price of non-tradables relative to tradables has risen to $P_{C}$. The real exchange rate - the inverse of this price ratio - has declined, corresponding to a real appreciation.

Now consider what this means for the rest of the economy, still characterized by the original production possibility frontier TN. Relative prices are now given by $P_{D}=P_{C}$ and production is at point $\mathrm{D}$. The non-traded goods sector has expanded relative to point $\mathrm{A}$ and the traded goods sectors (not including the new project or booming sector) has contracted. The contraction of these non-booming exporting and import-competing sectors, and what it 
implies for the people deriving their incomes from them, is the essence of the Gregory thesis / Dutch disease.

The general class of economic phenomena for which this analysis is a special case is as follows. Suppose one group in the society receives a windfall gain from outside. ${ }^{4}$ When it spends that gain there may be indirect economic effects on other members of the society who did not receive the windfall. These indirect effects may in some cases be positive, in others negative. In the Gregory thesis / Dutch disease example, the owners of specific factors used in the non-traded goods sector may be indirect beneficiaries of the spending, by others, of their windfall gains. But the owners of specific factors used in the tradables sectors may suffer.

Gregory's original 1976 presentation of this analysis rested on a partial equilibrium analytical framework. The general equilibrium version summarized above owes much to Snape (1977). Snape’s general equilibrium extension left the central insights derived by Gregory intact but added some important points: some tradables sectors can benefit from the boom while tradables in aggregate must contract; ${ }^{5}$ while non-tradables prices rise, nontradables production could increase (the expected outcome) or (in some special cases) decrease; and the relative price consequences of the boom produce magnified effects on specific factor returns - resource rents in the booming sector rise and specific factors in other tradables sectors contract in real terms. The latter point has clear distributional implications and subsequent general equilibrium treatments, including Corden and Neary (1982), Corden (1984) and Cassing and Warr (1985) analyzed these effects further. Most of these subsequent studies distinguished between the 'spending effect' of a booming sector or project, as emphasized in the above discussion, and the 'resource movement' effect, meaning the attraction of domestic resources directly into the booming sector or project itself.

\footnotetext{
${ }^{4}$ The analysis applies equally in reverse for a windfall loss, such as a natural or man-made disaster.

${ }^{5}$ Benjamin, et al. (1989) provide an empirical illustration of this outcome using a model similar to the World Bank 1-2-3 model described in (Devarajan, et al. 1993).
} 


\section{Relevance for Laos}

The NT2 project makes little use of domestic resources, except for the water and land used directly by the project. Its resource movement effect therefore seems minor, but the real appreciation induced by the project's spending effect is another matter. In the context of the Lao economy, it seems possible that a real exchange rate appreciation could have significant adverse consequences. Traded goods industries include much of the agricultural sector as well as the manufacturing sector, concentrated on garments production for export. Most of the poor people of Laos are employed in the agricultural sector. In 2002-03, 77 per cent of the Lao population resided in rural areas, but poverty incidence in rural areas (the proportion of the rural population with real expenditures below the poverty line) was almost double that of urban areas. Rural areas accounted for 86.5 per cent of all poor people. ${ }^{6}$ As in most poor countries, poverty in Laos is overwhelmingly rural. External events which harm the agricultural sector could have important consequences for poverty incidence. Similarly, the export-oriented garment industry employs a significant number of low-skilled Lao people who would otherwise be very poor. A sizeable contraction in this industry may also have unwelcome consequences for poverty incidence.

Is the NT2 project likely to lead to serious Gregory thesis / Dutch disease consequences within Laos? If so, how would this affect poverty incidence, especially in rural areas? One of the criticisms of the NT2 project has been exactly this. Some effects of this kind are presumably inevitable, a normal consequence of the absorption of large amounts of foreign exchange into the domestic economy. Similar effects follow from the absorption of the foreign exchange that comes with foreign aid and direct foreign investment. But in the case of NT2, how large might they be? Are the concerns about these matters justified?

\footnotetext{
${ }^{6}$ It can be shown that the share of rural areas in the total number of poor people is given by $s_{R}^{P}=\alpha_{R} P_{R} / P$, where $\alpha_{R}$ is the share of the total population residing in rural areas, $P_{R}$ is the share of the rural population that is poor (that is, the headcount measure of poverty incidence in rural areas) and $P$ is the share of the total population that is poor.
} 
The remainder of this paper is in five sections. The following section briefly charts the recent economic history of Laos, with a focus on the macroeconomic and related variables of interest for this study. The next section summarizes the NT2 project in terms which are comparable with the macroeconomic dimensions of the Lao economy and the following section brings these two sets of data together to speculate on the likely macroeconomic consequences of NT2. Because this form of historical analysis is inherently inconclusive, the next section constructs a simple two sector, multi-household computable general equilibrium (CGE) model of the Lao economy to analyze the issues discussed in the paper, with a focus on the consequences for poverty incidence. The final section concludes.

\section{Macroeconomic overview of $\operatorname{Laos}^{7}$}

\section{Real Sector}

Laos is a particularly poor country, with GDP per person in 2003 at US\$ 320, and total GDP of US\$ 1.8 billion. In 2002-03 roughly one third of the Lao population of 5 million were officially classified as poor. From 1991 to 2003 annual growth of GDP averaged 6.2 per cent per annum (annual data are in Figure 2), or around 3.8 per cent per person. The agricultural sector dominates in employment, with 80 per cent of the workforce and it contributes about 50 per cent of GDP. Laos receives substantial external support. In 2002-03 external donors contributed 61 per cent of the government's capital budget, representing 39 per cent of total public expenditure and 7.6 per cent of GDP.

Since the late 1980s, a program of market oriented economic reforms, known as the New Economic Mechanism (NEM), has moved the Lao economy away from the rigidly socialist pattern instituted immediately after the declaration of the Lao PDR in 1975. The reform process has produced significant structural change. The agricultural sector contracted

\footnotetext{
${ }^{7}$ The macroeconomic data summarized in this section are derived primarily from the National Statistical Centre, Vientiane, particularly the Statistical Yearbook, various issues, and the National Economic Research Institute, Vientiane, NERI Economic Monitor, various issues.
} 
from 61 per cent of GDP in 1990 to 50 per cent in 2002, a phenomenon typical of growing economies. Most of this contraction occurred in the crops sector, but it is significant for later discussion that the contraction of the crops sector was concentrated in the first half of the 1990s, when its share in GDP declined from 37 to 25 per cent. From then until the present, crops output recovered to around 30 per cent of GDP. Heavy public investment in irrigation in the second half of the 1990s accounted for this change.

One feature of the changes in the crop sector is important. The total area planted to rice remained virtually unchanged from 1990 to 2000, but within this the irrigated rice sector expanded very markedly, responding to the irrigation investments mentioned above, and the upland rice area (non-irrigated) contracted by 70 per cent. Rice became a less attractive activity for upland people. Several factors contributed to this change. One was the improved possibility of producing crops other than rice with market outlets both within Laos and in neighboring countries. The change resulted mainly from the progressive removal of earlier prohibitions on inter-provincial trade in rice. These prohibitions had been motivated by the policy that all regions of the country should strive for rice self-sufficiency, but the outcome was highly inefficient. The relaxation of the restrictions on inter-provincial trade in rice made it possible for regions lacking a comparative advantage in rice production to purchase the rice they required for consumption using the proceeds from sales of other commodities. Road improvement within Laos also played a role, making production of cash crops more feasible for producers previously constrained by poor or non-existent roads to produce rice for subsistence. Finally, relative price changes within Laos reduced the profitability of rice production. These changes are discussed under 'Capital flows and the real exchange rate', below. 
Inflation was moderate through the first half of the 1990s, at single digit levels for most of this period, but accelerated from 1998 to 2000, with the annual rate peaking at 134 per cent in 1999 (Figure 2). This inflationary surge was related to agricultural policy. The government of Laos is committed to a goal of rice self-sufficiency at a national level. However, it was apparent through the first half of the 1990s that rice output was not growing as fast as population. Illegal imports from Thailand apparently made up most of the shortfall. A massive public investment in irrigation facilities followed, but it was financed to a considerable extent by monetary creation, producing the inflation of the late 1990s. Since 2001 consumer price inflation has been contained, with an average annual rate just under 10 per cent.

Figure 3 shows that the inflation in consumer prices in the late 1990s coincided with a collapse of the exchange rate. The kip / dollar rate collapsed from roughly 2,000 at the end of 1997 to 8,200 at the end of 2001. Since Thailand is the major trading partner of Laos it is relevant to look at kip / baht exchange rates as well. Although the baht also depreciated in the late 1990s, as a result of Thailand's financial crisis, the kip's depreciation was much larger. The kip / baht rate declined from 47 at the end of 1997 to about 200 at the end of 2000.

\section{External Sector}

The volume of imports has exceeded exports in every year since the early 1990s. The current account deficit has averaged 12 per cent of GDP since 1991 (Figure 4). The deficit is financed by inflows on capital account. Foreign aid alone contributes about 8 per cent of Lao GDP.

\section{Capital inflows and the real exchange rate}

Figure 5 shows a series of relative prices corresponding approximately to the ratio of traded to non-traded goods prices. This is the ratio of food prices to services prices. Because 
producer prices are unavailable, this figure draws on consumer price data, disaggregated by commodity category, collected by the National Statistical Centre, Vientiane. These data indicate that agricultural commodity prices declined markedly relative to non-agricultural prices, especially from 1990 to 1994. An economic boom followed the more open economic environment created from 1988 onwards by the market-oriented NEM reforms, as described above, but this boom was concentrated in the services and construction sectors of the economy, concentrated in Vientiane, which drew resources from elsewhere, especially from agriculture.

The increased domestic expenditures made possible by foreign aid and foreign investment inflows produced demand-side effects that induced contraction of agriculture. Non-tradable prices rose because these goods and services cannot be imported or diverted from export. They include most services and construction. As their prices rose relative to those of traded goods their production became more profitable, attracting resources, including labour, away from agriculture, exactly as predicted by the Gregory thesis / Dutch disease analysis. To the extent that the NEM increased the exposure of agricultural commodities to international markets, this policy change indirectly increased the impact that these market phenomena had on agricultural production.

From 1997 to 1999 this real appreciation was reversed by the massive nominal depreciation described above. The mechanism is that a nominal depreciation increases the nominal domestic prices of traded goods. Some stickiness in non-traded goods prices caused them to respond slowly to the monetary expansion that was occurring at the same time, with the result that the ratio of traded goods prices to non-traded goods increases temporarily. This effect ceased after 1999 and real appreciation resumed.

Figure 5 combines this relative price series with data on two other measures of real exchange rates, also commonly called measures of 'competitiveness'. Both are based not on domestic relative prices, but on nominal exchange rates adjusted by foreign and domestic price 
levels. The general form of these measures is

$$
E^{R}=E P^{*} / P
$$

where $E$ denotes the nominal exchange rate, measured in units of domestic currency per unit of foreign currency, $P^{*}$ is a measure of foreign prices, measured in foreign currency, and $P$ is a measure of domestic prices, measured in domestic currency. The measures chosen for $P^{*}$ vary in different studies. The series called RER 1 uses foreign (US) consumer prices while RER 2 uses foreign (US) producer prices. Both series use Lao consumer prices for $P$. Each of the three series shown in Figure 5 is indexed to January $1988=100$.

The index labeled RER 2 is preferable to RER 1 as a proxy for traded goods prices relative to non-traded goods prices because the share of traded goods in wholesale price indices is higher than its share in consumer price indices. Thus the numerator of this index may be taken as a (very rough) proxy for domestic traded goods prices and the denominator, the domestic consumer price index, may be taken as a (very rough) index of domestic non-traded goods prices. Both of these exchange rate based measures, but especially RER 1, may be expected to understate the magnitude of a real appreciation arising for reasons other than an exchange rate movement, compared with changes in the domestic relative prices of traded goods to non-traded goods. The reason is that even if the numerator, $E P^{*}$, provides a good indicator of traded goods prices the denominator, $P$ - an index of domestic prices - contains both traded and non-traded goods prices. These indices will also overstate both the magnitude of the real depreciation resulting from a nominal depreciation and its duration. ${ }^{8}$

These features are exhibited exactly by the data in Figure 5. The relative price series shows the largest real appreciation from 1990 to 1994. RER1 and RER2, but especially RER 1, indicate large real appreciations arising from the nominal exchange rate depreciations of the late 1990s and also suggest that the real depreciations were longer-lived than they really were. The message

\footnotetext{
${ }^{8}$ See Warr (1986) for a demonstration of these results.
} 
conveyed by this diagram is then itself summarized in Table 1, by calculating averages for each of three periods: 1988 to 1994; 1995 to 1999; and 2000 to 2003. These three periods corresponded to a real appreciation, a real depreciation and a real appreciation, respectively, by each of the three measures shown, but the magnitudes differ in the directions predicted by the theoretical discussion outlined above.

\section{Capital Inflows}

We are interested in the relationship between inflows of foreign capital and the real exchange rate. Consider the balance of payments accounting identity

$$
\Delta R=C A B+K A B,
$$

where $\Delta R$ denotes the change in the level of official reserves, $C A B$ denotes the current account balance (positive if the current account is in surplus, negative if in deficit), and $K A B$ denotes the balance on capital account. Alternatively, rearranging this expression,

$$
K A B=\triangle R-C A B=\triangle R+C A D
$$

where $C A D=-C A B$ denotes the level of the current account deficit (positive if the current account is in deficit).

Now suppose there is an exogenous inflow of external resources. It could be foreign aid, foreign investment or royalty payments for electricity exports. This increases the left hand side of equation (3). This inflow may have effects on productivity and output in the medium term, but in the short term the inflow of foreign capital will be reflected in the two right hand components of equation (3): there will be some combination of an increase in foreign exchange reserves of the central bank and a current account deficit. Official reserves will increase to the extent that the inflow is 'sterilized' by the domestic monetary authority and thereby not absorbed into domestic spending; the current account deficit will increase to the extent that this does not happen and the capital inflow is absorbed into the domestic economy. It is therefore possible to interpret the magnitude of the current account deficit as that part of 
the surplus on capital account that is absorbed domestically, rather than 'saved' in the form of an increase in official reserves.

The 'saved' part of an exogenous capital inflow has no effect on the domestic real exchange rate, or any other domestic variable, because it does not affect domestic spending. So far as current macroeconomic effects are concerned, the relevant part of the capital inflow is the absorbed component, reflected in the magnitude of the current account deficit. In what follows, we interpret the magnitude of the capital account surplus and decisions on official reserves as exogenous. We wish to see the extent to which the absorption of capital inflows resulted in real exchange rate appreciations and thus, potentially, to Gregory thesis / Dutch disease effects on the domestic economy.

Table 1 applies the above reasoning to the data on real exchange rates discussed above and the data on the current account deficit reviewed in Figure 4. The period 1988 to 2003 is divided into three segments:

(i) 1988 to 1994: post-reform adjustment;

(ii) 1995 to 1999: hyperinflation and exchange rate depreciation; and (iii) 2000 to 2003: sustained growth with capital inflow.

It is helpful to focus on the first row of the table (Relative price - tradables / nontradables), which shows the annual average rate of relative price changes, expressed as a percentage, from Figure $5 .{ }^{9}$ For the reasons summarized above, this series (labeled 'Relative price' in Figure 5) is considered a better approximation to the real exchange rate than either of the other two (RER 1 and RER 2 in Figure 5). Now consider the three periods outlined above. Consistent with the 'Dutch disease' literature, the discussion will draw a connection between the level of the current account deficit - an annual flow indicating the annual rate of capital inflow - and changes in the level of the real exchange rate. This relationship will

\footnotetext{
${ }^{9}$ For example, if the index changed from a value of 50 to 40 over a period of 2 years, the annual average percentage rate of change would be calculated as $-[(10 / 2) / 50] * 100=-10 \%$.
} 
subsequently be used to extrapolate the future impact of current account deficits arising out of NT2 foreign exchange receipts, during construction and then during operation.

Period (i) - 1988 to 1994 - combined two events of relevance for this study. First, there was the opening of the Lao economy through the relaxation of severe quantitative restrictions on imports and some exports - a component of the NEM discussed above. Second, there was a substantial capital inflow, mainly through official foreign aid, which accompanied the liberalization program. This was reflected in large current account deficits, as shown in Figure 4. The effect of trade liberalization on the real exchange rate is indeterminate, but the capital inflow will have produced a real exchange rate appreciation. The effects of the capital inflow are relevant for this study, but the effects of the liberalization program are not. However, these two impacts on the real appreciation that occurred during this period are combined in the data and it is not obvious how their respective effects could be disentangled. Consequently, looking at the relationship between the size of the current account deficit and the rate of real appreciation during this period might not provide a reliable indication of the degree to which larger current account deficits alone, arising from capital inflow, would increase the rate of real appreciation.

Period (ii) - 1995 to 1999 - was a period of macroeconomic turmoil, both in Laos and elsewhere in the region. In Laos, this was a period of monetary instability, hyperinflation and nominal exchange rate chaos. To a lesser extent this was also the case in neighboring Thailand, Laos' major trading partner, except that in Thailand there was no hyperinflation. The effects this instability had on the real exchange rate presumably dominated any effect of capital inflows. The real depreciation that occurred during this period was a consequence of the nominal depreciations increasing the domestic prices of traded goods relative to the (temporarily stickier) prices of non-traded goods and services. This period may be 
disregarded as an indicator of the underlying macroeconomic relationship of interest in this study because a period of nominal exchange rate stability is required for this purpose.

Period (iii) - 2000 to 2003 - seems more suitable for revealing the relationships of interest. Current account deficits of 6.5 per cent of GDP coincided with rates of real appreciation of 2.8 per cent per annum, which is 36 per cent of the rate of appreciation that occurred during period (i) - 1988 to 1994. Using this relationship between the rate of real appreciation and the ratio of the current account deficit to GDP, estimated from period (iii), to extrapolate to period (i), the somewhat higher rate of capital inflow during period (i) relative to GDP apparently produced about half of the real appreciation that occurred during that period, with reform and other events responsible for the remaining half.

\section{Poverty Outcomes}

Studies of poverty incidence in Laos are constrained by the limited availability of household survey data sets which can support this form of analysis. The only such data sets available are assembled by the government's National Statistical Center and are known as the Lao Expenditure and Consumption Survey (LECS). Three such surveys have been conducted to date:

LECS 1, covering 1992-93;

LECS 2 covering 1997-98; and

LECS 3, covering 2002-03.

According to estimates from the World Bank office in Vientiane, over this 10 year period poverty incidence in Laos declined from 46 per cent to 34 per cent of the population, that is, by 1.2 per cent of the population per year. ${ }^{10}$ This compares favorably with Cambodia

\footnotetext{
${ }^{10}$ Source: Richter, van der Weide and Souksavath (2005), using data from the LECS surveys, National Statistical Centre, Vientiane. Over the same decade, reported urban poverty incidence declined from 26.5 to 19.7
} 
(0.5 per cent decline per year over the five years ending in 2001) ${ }^{11}$ and Thailand (1.6 per cent per year over the 33 years ending in 2002) ${ }^{12}$, but is less than Vietnam's reported rate of decline (roughly 3 per cent of the population per year over the 5 years ending in 2001). ${ }^{13}$

It is significant that the real appreciations noted above, and the resulting decline in the profitability of agricultural production, did not prevent large reductions in poverty incidence from occurring. These reductions occurred in both rural and urban areas. Moreover, during the two intervals $1992-93$ to $1997-98$ and then $1997-98$ to $2002-03$, the annual rates of rural poverty reduction were 1.9 and 1 per cent per year, respectively, despite the fact that the rate of real appreciation was much larger in the former case - almost three times. Of course, other things were happening at the same time and these must have contributed to the poverty outcomes which were observed. But this evidence shows that significant real appreciation does not, in itself, necessarily imply that rural (or urban) poverty incidence will increase.

\section{Macroeconomic Dimensions of the NT2 Project}

The project occurs over two distinct periods:

(i) construction period - 2004-2009; and

(ii) operational period - 2010-2020.

\section{Construction Period - 2004 to 2009}

The Lao government's contribution to the project’s capital cost is small - around US\$ 77 million, or about 7.5 per cent, of the total project capital cost of US\$ 1.03 billion. Estimated Gross Fixed Capital Formation (GFKF) in Laos, excluding hydro-power investment over the

\footnotetext{
per cent, 0.7 per cent per year, and rural poverty incidence declined from 51.8 to 37.6 per cent, 1.4 per cent per year. For an earlier study of changes in poverty incidence, based on similar data. see Kakwani, et al. (2002). ${ }^{11}$ Source: World Bank, (2002), Appendix Table 8.

${ }^{12}$ Source: Warr (2005) based on data from National Economic and Social Development Board, Bangkok. These estimates for Thailand are based on household income data, rather than expenditures as is the case with Laos, Cambodia and Vietnam.

${ }^{13}$ Source: World Bank, (2002), Appendix Table 8.
} 
construction period of the project is around US\$ 740 million per year. While the total capital investment of the project is equivalent to 1.35 years of total GFKF in Laos, the Lao contribution to this total investment cost is only 1.2 months of Lao annual GFKF and this amount is spread over 5 years. Comparing the total capital cost of the project with Lao annual GFKF is potentially misleading in the sense that if the NT2 project was not undertaken, this capital would not be available for investment in Laos.

Of the total capital cost of US\$ 1.03 billion, around US\$ 700 million is for imported goods and services. The imported goods will have roughly no impact on the Lao economy, other than their contribution to the project itself, unless they have some residual value at the end of the project. The foreign-supplied services will similarly have an effect only to the extent that the payment for these services is spent within Laos. There will inevitably be effects of this kind. Domestic civil works contracts will be worth about US\$ 300 million spread over five years. This, plus the spending of service providers within Laos, constitutes the capital inflow during the construction period whose macroeconomic effects require consideration.

Considering US\$ 300 over five years as an annual flow of US\$ 60 million per year, this amount represents 4 per cent of Lao GDP in 2003, equivalent to 61 per cent of the annual absorption of capital inflows into Laos (current account deficit) that occurred over the period 2000 to 2003. Thus the capital inflow may be projected to contribute to an increase in the rate of real appreciation in Laos of about 60 per cent of the amount which occurred over that period, or 1.7 per cent per year.

This calculation excludes the fact that some of the imported services used in the project will result in spending in Laos. However, it also ignores the fact that a substantial proportion of the domestic civil works contracts analyzed will themselves require imported capital goods. It seems probable that the second omission is more significant than the first. Thus the rate of real appreciation projected above is probably an upper bound on the actual rate. The 
calculation also ignores the fact that during the five-year period of the project the Lao economy will be larger than it was in 2003 and its relative magnitude will thus be somewhat smaller than the calculations above assume.

\section{Operational Period - 2010-2020}

Over the operating life of the project, expected to be 25 years, the Lao government will receive a stream of royalty and tax payments from the project. This income stream is an injection into the Lao economy, with macroeconomic effects analogous to those considered above. The amount of this income stream is equivalent to an annuity of not less than US\$ 25 million and not more than US\$50 million per year. These amounts are equivalent to 1.7 and 3.4 per cent, respectively, of Lao GDP in 2003 and 14 and 28 per cent of total government tax revenue in that year. Following the calculations above, this will have a real appreciation effect which would add 25 to 50 per cent to the rate of real appreciation that would otherwise have occurred. That is, it would result in an addition to the rate of real appreciation of 0.75 to 1.5 percentage points per year. Again this calculation ignores the fact that real GDP in Laos will be substantially higher in the operational phase of the project than it was in 2003, so it too must be considered an upper bound on the likely true rate.

Furthermore, the estimated relationship between the level of the current account deficit and the rate of real appreciation which is used in these calculations makes no allowance for the fact that some real appreciation can be expected as a consequence of the growth that was occurring. It is well known that economic growth increases the demand for non-tradables, raising their prices relative to those of tradables, whose prices are determined internationally. That is, increases in real incomes cause some real appreciation. In so far as the discussion above attributes all of the real appreciation that occurred between 2000 and 2003 to the level of the current account deficits that occurred during that period, ignoring the effect of the growth that was also occurring, it potentially overstates the effects that capital inflow have on 
the real exchange rate. Again, the resulting estimates must be considered an upper bound on the likely true rates.

In summary, during the period 2000 to 2003, real appreciation occurred at the rate of about 2.8 per cent per year. It is estimated that during the construction phase of the project (2004 to 2009), spending within Laos will add about 60 per cent of this amount, or about 1.7 per cent per year, to the rate of real appreciation that would otherwise have occurred. This effect will cease when the construction phase is completed, scheduled for 2009. During the operational phase, beginning in 2010, the spending of project income within Laos will add 0.75 to 1.5 per cent per year to the real appreciation that would otherwise have occurred. This is equivalent to 25 to 50 per cent of the annual rate of real appreciation actually observed between 2000 and 2003.

The net effects that the absorption of the NT2 revenues will have on Lao people will reflect the fact that national income and government revenue will increase as a result of the revenues earned from NT2. The manner in which these revenues are spent within Laos will influence their effects. If the revenues are spent in a way that benefits rural people the net effect will be quite different from those resulting if the revenues are misused. Experience elsewhere suggests that the net effect of large revenues from natural resource extraction depends heavily on this matter.

\section{A Small, Multi-household CGE Model of the Lao Economy}

We now draw upon a small CGE model of the Lao economy constructed to analyze the issues discussed in this paper. The model draws upon the structure of the famous '1-2-3' CGE model constructed by World Bank scholars (Devarajan et al. 1993), explicitly in the spirit of the Salter framework outlined in the first section of this paper and described in Figure 1, above The 1-2-3 model has two produced goods, an export and a 'domestic' (non-traded) good, produced jointly by a production process in which factors of production are not 
explicitly recognized. There are two consumed goods, the domestic good and an import, which are imperfect substitutes in consumption. There is only one consumer. The export good is not consumed domestically and the import good is not produced domestically. The extreme simplicity of the model is its strength for clarity of understanding, but also its weakness for empirical application.

\section{A Two Sector, Multi-household Model}

To analyze the issues of interest in this paper we amend the 1-2-3 model structure as follows. ${ }^{14}$ First, there are two sectors, an agricultural and a non-agricultural sector, each of which resembles the 1-2-3 model structure in that it jointly produces two goods - an export and a non-traded good. The two exported goods are not consumed domestically. Corresponding to each sector there is also an imported good which is not produced domestically. Four goods are therefore produced - two exports and two non-tradables - and four goods are consumed - the two non-tradables and the two imports.

In each of the two sectors two factors of production are used, producing the composite output of that sector. The factors are labour, which is mobile throughout the economy and a specific factor in each sector. In the agricultural sector we call this specific factor 'land' and in non-agriculture we call it 'capital', but these are merely labels for all of the specific factors used in these two sectors.

The distinctive feature of this model is its disaggregation of households. The reason for this treatment is that the focus of the analysis is at least in part to analyse changes in poverty incidence and inequality. There are 100 urban and 100 rural households. The 100 urban households are arranged by expenditure per capita into 100 groups of equal population sizes centile groups - arrayed from the poorest to the richest. The 100 rural households are arranged similarly. The resulting 200 household categories differ in three dimensions: their

\footnotetext{
${ }^{14}$ The full equation set for the model is provided in Appendix B.
} 
initial levels of real expenditures per capita; the sources of their incomes; and their expenditure pattern on final goods and services. The characteristics of these households, in terms of these three dimensions, are drawn from the 2002-03 LECS household income and expenditure survey, described above.

The LECS survey contains 8,800 households, 2312 urban and 6488 rural, which are aggregated into the 200 household categories described above. The expenditure shares of the households are calculated from the LECS survey data. Each household obtains income from ownership of the three factors of production: labour, land and capital, and from transfers, again drawing these data from the LECS survey. Because the sources of income and total income data are known to be less reliable than the expenditure data, we imposed the assumption that total income is equal to total expenditure for each household, scaling total income to match total expenditure. In addition, the sources of income were smoothed across the sample by fitting a linear regression to the income shares given by the data.

The 200 households are fully integrated into the structure of the CGE model. Total demand for each commodity is explicitly aggregated from the demand functions of the 200 individual households. This treatment improves upon the ‘tops-down' treatment common in multi-household CGE models, in which the demand behaviour of the multiple households is not integrated into the CGE structure; instead, relative prices (and sometimes quantities) derived from a simplified CGE structure are imposed on the multi-household data derived from household survey data, but without any general equilibrium feedback. The 'tops-down' approach thus gives rise to the concern that the simplified demand structure used in the CGE model may be inconsistent with the aggregate implications of the demand behaviour of the multiple households. These departures from a true general equilibrium structure are eliminated by the approach taken in this paper.

Each household derives income from ownership of the three factors of production, whose returns are determined endogenously within the model, and from transfers received 
from the government, which are exogenous. The role of the government is simply to receive transfers from abroad and then allocate them to households in ways that it determines. We wish to use the model to analyze the way in which various patterns of transfer translate into reduced or increased urban and rural poverty. This requires calculating the change in the level of real expenditures for each household and from this calculating changes in poverty incidence. We do this for the rural and urban households and then aggregate the results, weighted by population shares, to obtain aggregate poverty incidence.

\section{Decomposition of Changes in Real Expenditures}

We now derive a decomposition of the change in the real expenditures of an individual household. For simplicity, we shall assume that income is equal to expenditure for each household. Upper case Roman letters, like $X$, will denote levels of variables, $d X$ will denote the absolute change in its level and lower case Roman letters, like $x$, will denote proportional change. Thus $x=d X / X$. By definition, the proportional change in the nominal expenditure of household $h$ is given by $y_{h}=\tilde{y}_{h}+p_{h}$, where $\tilde{y}_{h}$ is the proportional change in the household's real income and $p_{h}=\sum_{i=1}^{I} S_{h}^{i} p^{i}$ is the proportional change in a consumer price index specific to household $h$, with $S_{h}^{i}=E_{h}^{i} / Y_{h}$ denoting that household's expenditure share on commodity $i, E_{h}^{i}$ denoting its nominal expenditure on commodity $i$ and $p^{i}$ denoting the proportional change in the consumer price of commodity $i$. The absolute change in this household's nominal expenditures is now

$$
d Y_{h}=Y_{h} y_{h}=Y_{h} \tilde{y}_{h}+Y_{h} p_{h}
$$

Now, noting that the base levels of nominal and real expenditures are equal $\left(Y_{h}=\tilde{Y}_{h}\right)^{15}$, the change in nominal expenditures of the household is given by the change in its real income plus

\footnotetext{
${ }^{15}$ Real expenditures means expenditures measured at constant prices, defined here to mean base period prices. Thus, the levels of nominal and real expenditures in the base period are identical.
} 
the change in its cost of living, the latter an expenditure weighted sum of the changes in the consumer prices it faces:

$$
d Y_{h}=d \tilde{Y}_{h}+\sum_{i=1}^{I} E_{h}^{i} p^{i}
$$

On the income side, total income is given by transfer income, $T_{h}$, plus factor income, $Y_{h}^{f}$. Thus the change in nominal income is given by

$$
d Y_{h}=d T_{h}+d Y_{h}^{f}
$$

Now, rearranging these expressions,

$$
d \tilde{Y}_{h}=d T_{h}+d Y_{h}^{f}-\sum_{i=1}^{I} E_{h}^{i} p^{i} .
$$

The change in the household's real expenditures is therefore decomposable into three parts: the change in its receipt of transfers plus the change in its factor income minus the change in its cost of living.

\section{Results}

The results are summarized in Tables 2 to 5 . Four simulation experiments are reported. In each case an inflow of US\$ 50 million per year (roughly 500 billion Lao kip at the 2003 exchange rate of 10,000 kip per \$US) is received by the government in the form of royalties on electricity exports. ${ }^{16}$ The government then distributes this to Lao households in the following manner.

Simulation 1: All transfers go to the richest 10 per cent of urban households, distributed among them in equal lump sum amounts. Poor households receive no direct benefits. This simulation captures the (hopefully remote) possibility that all proceeds from the project are corruptly appropriated by senior government officials.

\footnotetext{
${ }^{16}$ As discussed above, the resource movement effect of the project seems minor and the discussion here focuses on its spending effects.
} 
Simulation 2: All proceeds go to urban households and are distributed among them in equal lump sum amounts. Poor urban households share in these benefits but no rural households receive them. This simulation captures the possibility that the proceeds are spent in a way that benefits only urban households.

Simulation 3: The proceeds are distributed across the entire population in equal lump sum amounts. Poor rural and urban households share in these direct benefits.

Simulation 4: All proceeds go to rural households and are distributed among them in equal lump sum amounts. Poor rural households share in these direct benefits but no urban households receive them.

The results confirm the qualitative predictions of the Gregory thesis / Dutch disease analysis. Table 2 summarises the main general equilibrium results. In each case the real exchange rate - the ratio of traded to non-traded goods prices - declines, indicating a real appreciation, as predicted by the Gregory thesis / Dutch disease literature though, at somewhat higher rates than is suggested by the historical data, summarized above. The difference presumably reflects the inevitable arbitrariness involved in assigning actual price series to the categories 'traded' and 'non-traded' in the historical data.

The row marked 'Real exchange rate - relative price ratio' is the ratio of the price of traded goods to non-traded goods. The row marked 'Real exchange rate - competitiveness index' is the measure given by equation (1), above. ${ }^{17}$ The two real exchange rate measures move in the same direction, but for the reasons discussed above the change in the competitiveness index understates the real appreciation indicated by the decline in the traded / non-traded goods relative price. Exports contract in both the agricultural and non-agricultural sectors. In each of these sectors output shifts from the export to the domestic good. The nominal wage rises in each case as domestic demand is increased by the inflow. In all cases but simulation 1, the real wage also

\footnotetext{
${ }^{17}$ This 'competitiveness' index corresponds to the measures RER 1 and RER 2 in the above discussion. Because foreign producer prices and foreign consumer prices are both held constant in these simulations, the measures RER 1 and RER 2 are identical in this case.
} 
increases. $^{18}$

The results further indicate that the manner in which the transfers are distributed greatly affects the outcome on poverty incidence. As an aid to understanding the subsequent discussion, the last two rows of Table 2 show the effects on the real expenditures of a representative urban and rural poor household, respectively. The households chosen are those initially on the threshold of the urban and rural poverty lines, respectively. ${ }^{19}$ In simulation 1, poor households receive no direct transfers. The effects shown are thus the direct effects of the spending of the richest 10 per cent of urban households. The poor urban household benefits from these indirect spending effects and the rural poor household loses.

The reason for this result is made clearer by Tables 3 and 4, which apply the decomposition developed in equation (7), above. The proportional change in real factor income, the difference between the proportional changes in nominal factor income and the cost of living, is positive for the urban household and negative for the rural household. This pattern is repeated across each of the four sets of simulations. For the poor urban household, real factor income rises, and for the poor rural household it falls. These two tables also indicate the main reason for this difference. The cost of living of the poor rural household increases more, due to this household's greater propensity to purchase non-tradables, whose prices rise relative to tradables in all four simulations

The resulting effects on poverty are summarized in Table 5. Figures 6 and 7 illustrate the method used to compute changes in poverty incidence. Each figure shows a magnified segment of the cumulative distribution of real expenditures before and after Simulation 1. The relevant segment is that containing the intersection between this distribution and the poverty line, shown by the vertical line in each figure. Poverty lines constructed for Laos by the World Bank are used for this purpose and they are different for urban and rural areas, reflecting the higher cost of

\footnotetext{
${ }^{18} \mathrm{~A}$ feature if simulation 1 is that because the marginal propensity of the richest urban households to spend on nontradables is lower than other groups the real appreciation which results is smaller than in the other three cases and the increased demand for labour is also correspondingly smaller.

${ }^{19}$ These are the households corresponding to the 19th urban centile (arranged from poorest to richest) and the 37th rural centile, respectively.
} 
living in urban areas. Poverty incidence is given by the vertical intercept of the poverty line with the cumulative distribution. For the reasons indicated above, poverty incidence declines in urban areas under Simulation 1 and rises in rural areas. Because poor rural households are so much more numerous than poor urban households, aggregate poverty rises. Table 5 also shows the effects on inequality, as measured by the Gini coefficient. Urban inequality rises under Simulation 1 while rural inequality barely changes.

Obviously, the main differences in the four simulations arise from the receipt or non-receipt of direct transfers. Rural poverty incidence rises due to the indirect effects of urban spending described above, whenever the rural households receive no direct transfers. This occurs under Simulations 1 and 2. Urban poverty declines due to indirect spending effects in all cases, reflecting the greater propensity of urban poor households than rural poor households to spend on tradables, whose relative prices decline in each simulation. Under Simulation 2, urban poor households receive sufficient direct transfers to reduce urban poverty enough to outweigh the increase in rural poverty. Under Simulations 3 and 4 rural poor households receive direct transfers and rural poverty declines, along with total poverty.

\section{Conclusions}

The body of analysis commonly known in Australia as the 'Gregory thesis' was developed by Bob Gregory three decades ago in the context of a mineral export boom in Australia. Similar ideas, independently developed elsewhere, became known as the 'Dutch disease' analysis. The core insights of this analysis have enduring relevance throughout the world. This paper attempts to demonstrate this point in the context of Laos, a small transitional economy currently implementing a very large hydroelectric power project designed for the export of electric power to neighbouring Thailand. A small general equilibrium model of the Lao economy is used for this purpose. The results confirm the relevance of the economic insights developed by Gregory for economic policy in Laos today. 
The paper extends the analysis developed by Gregory and others to analyze the implications of the project for poverty incidence in Laos. The results confirm that the manner in which the proceeds of the project are distributed greatly affects its impact on poverty incidence. If poor households do not share directly in the proceeds of the project, the indirect effects of the spending of those who do receive the benefits imply that poverty incidence is likely to rise. The central issue is governance. It is crucial that effective measures be adopted to ensure that the revenues from the project are spent in ways that produce direct benefits for poor people, especially those in rural areas. Supplementary measures to protect rural people from the negative consequences resulting from the macroeconomic effects of this and similar large investment projects also seem appropriate. 


\section{REFERENCES}

Benjamin, N. C., Devarajan, S. and Weiner, R. J. (1989), 'The Dutch disease in a developing country: Oil reserves in Cameroon’, Journal of Development Economics 30, 71-92.

Cassing, J. H. and P. G Warr (1985), 'The distributional impact of a resource boom', Journal of International Economics 18, 301-320.

Corden W. M. (1981), ‘Exchange Rate Protection’, in Cooper, R. N., Kenen, P. B., De Macedo, J. B. and Yperselle, J. C. (eds), The International Monetary System Under Flexible Exchange Rates, Ballinger, Cambridge, Mass., 17-34.

Corden W. M. (1984), 'Booming sector and Dutch disease economics: Survey and consolidation’ Oxford Economic Papers 36, 359-80.

Corden, W. M. and J. P. Neary (1982), 'Booming sector and de-industrialization in a small open economy', Economic Journal 92, 825-48.

Datt, G. and Wang, L. (2001), ‘Poverty in Lao PDR: 1992/93 - 1997/98’, World Bank, Washington DC, mimeo.

Devarajan, S., Lewis, J. D. and Robinson, S. (1993) 'External shocks, purchasing power parity and the equilibrium real exchange rate’, World Bank Economic Review 7, 45-63.

Gregory, R. G. (1976), 'Some implications of the growth of the mineral sector', Australian Journal of Agricultural Economics 20, 71-91.

Kakwani N., Datt, G. Sisouphanthong, B., Souksavath, P. and Wang, L. (2002), 'Poverty in Lao PDR during the 1990s’, Asian Development Bank, Manila, mimeo.

Richter, K., van der Weide, R. and Sopuksavath, P. (2005), 'Lao PDR poverty trends 1992/3 - 2002/3’, Draft Report, Committee for Planning and Investment, National Statistical Center and World Bank, Vientiane.

Salter, W. E. (1959), 'Internal and external balance: The role of price and expenditure effects', Economic Record 35, 226-38. 
Snape, R. H. (1977), ‘Effects of mineral development on the economy’, Australian Journal of Agricultural Economics 21 147-156.

Warr, P. (1986), 'Indonesia's other Dutch disease: Economic effects of the petroleum boom', in Neary, J.P. and van Wijnbergen, S. (eds), Natural Resources and the Macroeconomy, Basil Blackwell, Oxford, 288-320.

Warr, P. (2005), 'Boom, Bust and Beyond' in Warr, P. (ed.), Thailand Beyond the Crisis, Routledge, London, 3-65.

World Bank, (2002), East Asia Rebounds, But How Far? World Bank, Washington. 


\section{Appendix A: Some web sites dealing with the Nam Theun 2 project:}

\section{$\underline{\text { Institutions }}$}

Nam Theun 2 Power Co. Ltd, Vientiane www.namtheun2.com

World Bank http://web.worldbank.org/WBSITE/EXTERNAL/COUNTRIES/EASTASIAPACIFICE XT/LAOPRDEXTN/0,,contentMDK:20172670 pagePK:141137 piPK:217854 theSite $\underline{\text { PK:293684,00.html }}$

Asian Development Bank http://www.adb.org/Documents/News/2005/nr2005042.asp

Powering ProgressThe website of the Lao National Committee for energy http://www.poweringprogress.org/

The Mekhong Research Centre http://www.mekong.es.usyd.edu.au/case_studies/nam_theun/nam_theun_2/nam_theun $\underline{2 . h t m}$

Ausaid Review of Nam Theun II http://www.ausaid.gov.au/publications/pdf/nt2_hydro_report.pdf

\section{$\underline{\text { NGOS }}$}

Probe International (NGO)

http://www.probeinternational.org/pi/index.cfm?DSP=content\&ContentID=11795

International Rivers Network

http://www.irn.org/programs/mekong/namtheun.html http://www.dams.org/docs/kbase/submissions/ins173.pdf http://www.irn.org/programs/mekong/Legacy_of_hydro_low.pdf

Rivers Watch East and Southeast Asia

http://www.rwesa.org/nam_theun.html

Global response

http://www.globalresponse.org/emailcampaigns.php?record=2054

Environmental defense

http://www.environmentaldefense.org/article.cfm?ContentID=4137

FIVAS-Association for International Water and Forest Studies http://www.fivas.org/prosjekt/laos/laos_index.html

Bretton Woods Project, Critical voices on the World Bank and IMF

http://www.brettonwoodsproject.org/article.shtml?cmd\%5B126\%5D=x-126-174503 
WWF-World Wildlife Fund

http://www.panda.org/about_wwf/what_we_do/freshwater/problems/infrastructure/dams lexamples/nam theun.cfm

People and Planet

http://www.peopleandplanet.net/doc.php?id=2363

Earth Hope Network

http://earthhopenetwork.net/Hydropower_Dam_Laos_Would_Alter_2_Rivers.htm

Aidwatch

http://www.aidwatch.org.au/assets/aw00687/Media\%20Release\%20Mar\%2005.pdf

Corporate Watch

http://www.corpwatch.org/article.php?id=12077

Worldwatch Institute

http://www.worldwatch.org/press/news/2005/03/28/

Radio Free Asia

http://www.rfa.org/english/news/business/2005/02/15/laos_dam/

Akha Heritage Foundation

http://www.akha.org/article274.html

Oxfam

http://www.oxfammekong.org/text_pages/omi_infrastruc.html

\section{Others}

Articles from The Vientiane Times:

http://www.vientianetimes.com/Lao_forum/01242002_opposition_to_funding_of_nam the.html

Articles from Bangkok Post

http://www.bangkokpost.net/150305_News/15Mar2005_opin42.php

Lao Embassy

http://www.laoembassy.com/news/namtheun2.html 


\section{Appendix B:}

\section{A Two-sector Multi-household CGE Model of the Lao Economy}

Lower case Roman letters indicate percentage change; upper case Roman letters indicate absolute levels. Thus $x=100 . d X / X$. Superscripts $a$ and $n$ indicate the agricultural and non-agricultural sector/commodity, respectively, and subscripts $E, D$ and $I$ indicate exports, domestic goods and imports, respectively.

\section{Production}

Factor demand

$$
\begin{array}{cc}
l^{j}=x^{j}-\sigma^{j}\left(1-S_{L}^{j}\right)\left(w-r^{j}\right), & j=\{a, n\}, \\
\bar{k}^{j}=x^{j}-\sigma^{j} S_{L}^{j}\left(r^{j}-w\right), & j=\{a, n\} .
\end{array}
$$

Zero profit in sectoral production

$$
p^{j}=S_{L}^{j} w+\left(1-S_{L}^{j}\right) r^{j}, \quad j=\{a, n\} .
$$

Export-domestic transformation

$$
\begin{array}{cc}
x_{D}^{j}=x^{j}+\Omega^{j}\left(1-S_{D}^{j}\right)\left(p_{D}^{j}-\bar{p}_{E}^{j}\right), & j=\{a, n\}, \\
x_{E}^{j}=x^{j}+\Omega^{j} S_{D}^{j}\left(\bar{p}_{E}^{j}-p_{D}^{j}\right), & j=\{a, n\} .
\end{array}
$$

Zero profit in product transformation

$$
P^{j} X^{j}\left(p^{j}+x^{j}\right)=P_{D}^{j} X_{D}^{j}\left(p_{D}^{j}+x_{D}^{j}\right)+P_{E}^{j} X_{E}^{j}\left(\bar{p}_{E}^{j}+x_{E}^{j}\right), \quad j=\{a, n\}
$$

Factor market clearing

$$
\bar{l}=S_{\bar{L}}^{a} l^{a}+\left(1-S_{\bar{L}}^{a}\right) l^{n} .
$$

\section{Household Income and Expenditure}

Household factor income

$$
y_{h}^{f}=S_{w h} w+S_{r h}^{a} r^{a}+S_{r h}^{n} r^{n} .
$$


Household total income

$$
Y_{h} y_{h}=Y_{h}^{f} y_{h}^{f}+\Delta \bar{T}_{h}^{G}
$$

\section{Household Demand}

Demand for commodity $j$ over subsistence

$$
\begin{array}{ll}
q_{D_{h}}^{j L}=y_{h}-p_{D}^{j}, & j=\{a, n\}, \\
q_{I_{h}}^{j L}=y_{h}-\bar{p}_{I}^{j}, & j=\{a, n\} .
\end{array}
$$

Total demand for commodity $j$ (luxury and subsistence)

$$
\begin{array}{ll}
q_{D_{h}}^{j}=B_{D_{h}}^{j L} q_{D_{h}}^{j L}+\left(1-B_{D_{h}}^{j L}\right) \bar{q}_{D_{h}}^{j s} & j=\{a, n\}, \\
q_{I_{h}}^{j}=B_{I_{h}}^{j L} q_{I_{h}}^{j L}+\left(1-B_{I_{h}}^{j L}\right) \bar{q}_{I_{h}}^{j s} & j=\{a, n\} .
\end{array}
$$

where $B_{j h}=-\varepsilon_{j h} / \phi_{h}$ is the ratio of supernumary expenditure to total expenditure of commodity $j$ by household $h$ and $\varepsilon$ is the expenditure elasticity of commodity $i$ by household $h$, and $\phi_{h}$ is the Frisch parameter of household $h$.

Total expenditure (to determine supernumary expenditure)

$$
E_{h} e_{h}=\sum_{j=\{a, n\}} P_{D}^{j} Q_{D_{h}}^{j}\left(p_{D}^{j}+q_{D_{h}}^{j}\right)+\sum_{j=\{a, n\}} \bar{P}_{I}^{j} Q_{I_{h}}^{j}\left(\bar{p}_{I}^{j}+q_{I_{h}}^{j}\right)
$$

Real household expenditure

$$
\left(\sum_{j=\{a, n\}} P_{D}^{j} Q_{D_{h}}^{j}+\sum_{j=\{a, n\}} \bar{P}_{I}^{j} Q_{I_{h}}^{j}\right) y_{h}^{R}=\sum_{j=\{a, n\}} P_{D}^{j} Q_{D_{h}}^{j} q_{D_{h}}^{j}+\sum_{j=\{a, n\}} \bar{P}_{I}^{j} Q_{I_{h}}^{j} q_{D_{h}}^{j}
$$

Ex post level of real household expenditure

$$
Y_{h}^{1}=Y_{h}^{0}\left(100+y_{h}^{1}\right),
$$

where $Y_{h}^{0}$ is the ex ante level of household expenditure of household $h$ and $y_{h}^{1}$ is the simulated percentage change in real expenditure of household $h$.

\section{Domestic Goods Market Clearing}




$$
x_{D}^{j}-\sum_{h} S_{D_{h}}^{j} q_{D_{h}}^{j}=0, \quad j=\{a, n\}
$$

\section{Macroeconomic identities}

Current account balance

$$
\Delta B=\sum_{j=\{a, n\}}\left[P_{E}^{j} X_{E}^{j}\left(\bar{p}_{E}^{j}+X_{E}^{j}\right)-P_{I}^{j} Q_{I}^{j}\left(\bar{p}_{I}^{j}+\sum_{h} S_{I_{h}}^{j} q_{I_{h}}^{j}\right)\right] .
$$

Real GDP (income side)

$$
\left(\sum_{j=\{a, n\}} \bar{P}^{j} X^{j}\right) g d p^{R}=\left(\sum_{j=\{a, n\}} \bar{P}^{j} X^{j} X^{j}\right)
$$

\section{Total number of equations:}

$17+13 . H$, where $H$ is the total number of households .

\section{Endogenous variables, not household specific (without h subscript)}

1) $l^{j}$ is labour use in sector $j, j=\{a, n\}, x^{j}$ is output of sector $j, j=\{a, n\}$

2) $w$ is the wage

3) $r^{j}$ is the price of capital in sector $j, j=\{a, n\}$

4) $p^{j}$ is the price of output in sector $j, j=\{a, n\}$

5) $x_{D}^{j}$ is output of sector $j$ supplied to the domestic market, $j=\{a, n\}$

6) $x_{E}^{j}$ is output of sector $j$ supplied to the export market, $j=\{a, n\}$

7) $p_{D}^{j}$ is the price of domestic commodity $j, j=\{a, n\}$

8) $\Delta B$ is the change in the current account balance

9) $g d p^{R}$ is real GDP

\section{Endogenous variables, household-specific (with $h$ subscript)}

1) $q_{D_{h}}^{j}$ is household demand for the domestic commodity $j, j=\{a, n\}$

2) $q_{I_{h}}^{j}$ is household demand for the imported commodity $j, j=\{a, n\}$

3) $q_{D_{h}}^{j L}$ is household luxury demand for the domestic commodity $j, j=\{a, n\}$

4) $q_{I_{h}}^{j L}$ is household luxury demand for the imported commodity $j, j=\{a, n\}$

5) $y_{h}$ is household income 
6) $y_{h}^{f}$ is household factor income

7) $e_{h}^{L}$ is household supernumary expenditure

8) $y_{h}^{R}$ is real household expenditure

9) $Y_{h}^{1}$ is ex post level of real expenditure

\section{Total number of endogenous variables:}

$17+13 . H$, where $H$ is the total number of households.

\section{Exogenous variables}

$\bar{k}^{j}$ is capital use in sector $j, j=\{a, n\}$

$\bar{p}_{E}^{j}$ is the export price of commodity $j, j=\{a, n\}$

$\bar{l}$ is the total labour endowment

$\bar{p}_{I}^{j}$ is the price of imported commodity $j, j=\{a, n\}$

$\bar{s}_{h}$ is household saving

$\Delta \bar{T}_{h}^{G}$ is the change in transfer from the government to household $h$

$\bar{q}_{D_{h}}^{i s}$ is household subsistence demand for domestic commodity $j, j=\{a, n\}$

$\bar{q}_{I_{h}}^{i s}$ is household subsistence demand for imported commodity $j, j=\{a, n\}$

\section{Parameters and coefficients}

$\sigma^{j}$ is the elasticity of substitution in sector $j, j=\{a, n\}$

$\Omega^{j}$ is the transformation parameter in sector $j, j=\{a, n\}$

$\alpha_{D}^{j}$ is the household budget share of domestic commodity $j, j=\{a, n\}$

$\alpha_{I}^{j}$ is the household budget share of imported commodity $j, j=\{a, n\}$

$S_{L}^{j}$ is the labour cost share in sector $j, j=\{a, n\}$

$S_{D}^{j}$ is the share of sector $j$ in domestic sales, $j=\{a, n\}$

$S_{\bar{L}}^{j}$ is the share of labour employed in sector $j, j=\{a, n\}$

$S_{w}$ is the household labour income share

$S_{r}^{j}$ is the household capital from sector $j$ income share $j=\{a, n\}$

$B$ is the nominal value of the current account balance

$P_{E}^{j} X_{E}^{j}$ is the initial nominal value of exports from sector $j, j=\{a, n\}$

$P_{D}^{j} X_{D}^{j}$ is the initial nominal value of domestic sales from sector $j, j=\{a, n\}$

$P_{I}^{j} Q_{I}^{j}$ is the initial nominal value of imports of commodity $j, j=\{a, n\}$ 
$P_{I}^{j} Q_{I}^{j}$ is the initial nominal value of imports of commodity $j, j=\{a, n\}$

$P^{j} X^{j}$ is the initial nominal value of output of sector $j, j=\{a, n\}$

$Y_{h}$ is initial value of total household income

$Y_{h}^{f}$ is the initial value of household factor income

$E_{h}$ is the initial value of household expenditure

$S_{h}$ is the initial value of household saving

$E$ is the initial value of aggregate expenditure

$I$ is the initial value of aggregate investment 
Table 1 Laos: Rates of change of real exchange rates and levels of current account deficits, 1988 to 2003

\begin{tabular}{|l|c|c|c|}
\hline \multicolumn{1}{|c|}{ Variable } & $\mathbf{1 9 8 8 - 1 9 9 4}$ & $\mathbf{1 9 9 5 - 1 9 9 9}$ & $\mathbf{2 0 0 0 - 2 0 0 3}$ \\
\hline $\begin{array}{l}\text { Relative price - tradables (food) / non- } \\
\text { tradables (services) } \\
\text { (average change, per cent per year) }\end{array}$ & -7.7 & +0.8 & -2.8 \\
$\begin{array}{l}\text { Real exchange rate 1 } \\
\text { (average change, per cent per year) }\end{array}$ & -4.5 & +10.1 & -0.4 \\
$\begin{array}{l}\text { Real exchange rate 2 } \\
\text { (average change, per cent per year) }\end{array}$ & -5.7 & +7.2 & -0.5 \\
$\begin{array}{l}\text { Current account deficits } \\
\text { (annual average, per cent of GDP) }\end{array}$ & 9.5 & 13.8 & 6.5 \\
\hline
\end{tabular}

Source: Author's calculations using data from National Statistical Center, Vientiane, and International Monetary Fund.

Note: A negative change in the real exchange rate (e.g. the relative price variable from 1988 to 1994) means a decline in the ratio of traded goods prices to non-traded goods prices; a positive change (e.g. the same variable from 1995 to 1998) means an increase in this price ratio. 
Table 2 Laos: Shocks and simulated effects on relevant variables

\begin{tabular}{|c|c|c|c|c|}
\hline \multirow{2}{*}{ Variable } & \multicolumn{4}{|c|}{ Simulation } \\
\hline & 1 & 2 & 3 & 4 \\
\hline \multicolumn{5}{|l|}{ Shocks - incoming transfers: } \\
\hline Urban transfer (billion kip) & 500.0 & 500.0 & 98.8 & 0.0 \\
\hline Rural transfer (billion kip) & 0.0 & 0.0 & 401.2 & 500.0 \\
\hline \multicolumn{5}{|l|}{ Changes in endogenous variables (\% change) } \\
\hline Agricultural output & -0.407 & 0.314 & 0.217 & 0.198 \\
\hline Non-agricultural output & 0.380 & -0.291 & -0.201 & -0.184 \\
\hline Agricultural export & -1.460 & -2.173 & -2.966 & -3.202 \\
\hline Non-agricultural export & -1.295 & -2.299 & -3.052 & -3.281 \\
\hline Total export & -1.419 & -2.205 & -2.988 & -3.222 \\
\hline Agriculture price & 2.149 & 5.151 & 6.669 & 7.149 \\
\hline Non-agriculture price & 3.422 & 4.154 & 5.970 & 6.506 \\
\hline Domestic agriculture price & 2.781 & 6.652 & 8.605 & 9.221 \\
\hline Domestic non-agriculture price & 4.675 & 5.671 & 8.137 & 8.864 \\
\hline Real exchange rate: relative price ratio & -3.083 & -6.056 & -7.840 & -8.380 \\
\hline Real exchange rate: 'competitiveness' index & -2.239 & -4.468 & -5.819 & -6.230 \\
\hline Nominal wage & 2.253 & 5.068 & 6.611 & 7.096 \\
\hline Nominal price of agricultural capital & 1.733 & 5.481 & 6.900 & 7.362 \\
\hline Nominal price of non-agricultural capital & 4.209 & 3.549 & 5.545 & 6.115 \\
\hline Consumer price index & 2.290 & 4.677 & 6.179 & 6.644 \\
\hline Real wage & -0.037 & 0.391 & 0.432 & 0.452 \\
\hline Real price of agricultural capital & -0.557 & 0.804 & 0.721 & 0.717 \\
\hline Real price of non-agricultural capital & 1.919 & -1.127 & -0.634 & -0.530 \\
\hline Real expenditure of poor urban household & 0.719 & 17.771 & 3.639 & 0.466 \\
\hline Real expenditure of poor rural household & -0.589 & -0.479 & 3.107 & 3.993 \\
\hline
\end{tabular}

Note: The representative poor urban and poor rural households used as the basis for the last two rows of the table are urban household 19 and rural household 37, which are the urban and rural households initially on the threshold of the urban and rural poverty lines, respectively.

Source: Author's calculations. 
Table 3 Laos: Simulated effects of incoming transfers on real expenditures of a representative poor household - urban

(Units: absolute and percentage changes in real expenditures)

\begin{tabular}{|l|c|c|c|c|}
\hline \multirow{2}{*}{$\begin{array}{l}\text { Change in real expenditures - } \\
\text { poor urban household }\end{array}$} & \multicolumn{3}{|c|}{ Simulation } \\
\cline { 2 - 5 } & $\mathbf{1}$ & $\mathbf{2}$ & $\mathbf{3}$ & $\mathbf{4}$ \\
\hline & & & & \\
Absolute change & 0.22 & 5.35 & 1.09 & 0.14 \\
Real expenditure & 0.82 & 1.41 & 1.91 & 2.06 \\
Nominal factor income & 0.00 & 5.00 & 0.99 & 0.00 \\
Transfer & -0.61 & -1.07 & -1.80 & -1.92 \\
Cost of living & & & & \\
& & & & \\
Percentage change & 0.72 & 17.77 & 3.64 & 0.47 \\
Real expenditure & 2.73 & 4.70 & 6.35 & 6.86 \\
Nominal factor income & 0.00 & 16.62 & 3.28 & 0.00 \\
Transfer & -2.01 & -3.54 & -5.99 & -6.39 \\
Cost of living & & & & \\
\hline
\end{tabular}

Note:

The representative poor urban household is urban household 19, which is the urban household initially on the threshold of the urban poverty line.

The change in real expenditure is in each case the sum of the changes in nominal factor income, transfer and cost of living (equation (6)).

Source: Author’s calculations. 
Table 4 Laos: Simulated effects of incoming transfers on real expenditures of a representative poor household - rural

(Units: absolute change and percentage change in real expenditures)

\begin{tabular}{|l|c|c|c|c|}
\hline \multirow{2}{*}{$\begin{array}{l}\text { Change in real expenditures - } \\
\text { poor rural household }\end{array}$} & \multicolumn{3}{|c|}{ Simulation } \\
\cline { 2 - 5 } & & & & \\
\hline & $\mathbf{1}$ & $\mathbf{2}$ & $\mathbf{3}$ & $\mathbf{4}$ \\
\hline Absolute change & & & & \\
Real expenditure & -0.61 & -0.48 & 3.21 & 4.12 \\
Nominal factor income & 2.14 & 5.41 & 6.96 & 7.46 \\
Transfer & 0.00 & 0.00 & 4.01 & 5.00 \\
Cost of living & -2.75 & -5.89 & -7.77 & -8.34 \\
& & & & \\
Percentage change & & & & \\
Real expenditure & -0.59 & -0.46 & 3.09 & 3.97 \\
Nominal factor income & 2.07 & 5.22 & 6.72 & 7.19 \\
Transfer & 0.00 & 0.00 & 3.87 & 4.82 \\
Cost of living & -2.65 & -5.68 & -7.49 & -8.04 \\
\hline
\end{tabular}

Note:

The representative poor rural household is rural household 37 which is the rural household initially on the threshold of the rural poverty line.

The change in real expenditure is in each case the sum of the changes in nominal factor income, transfer and cost of living (equation (6)).

Source: Author's calculations. 
Table 5 Laos: Simulated effects on poverty and inequality

\begin{tabular}{|l|c|c|c|c|}
\hline & \multicolumn{3}{|c|}{ Simulation } \\
\cline { 2 - 5 } & $\mathbf{1}$ & $\mathbf{2}$ & $\mathbf{3}$ & $\mathbf{4}$ \\
\hline Effects on poverty (\%) & & & & \\
& & & & \\
Ex-ante poverty - rural & 37.60 & 37.60 & 37.60 & 37.60 \\
Ex-post poverty - rural & 0.50 & 38.04 & 35.20 & 34.62 \\
Change & & 0.44 & -2.40 & -2.98 \\
& 19.70 & 19.70 & 19.70 & 19.70 \\
Ex-ante poverty - urban & 19.42 & 10.75 & 17.73 & 19.50 \\
Ex-post poverty - urban & -0.28 & -8.95 & -1.97 & -0.20 \\
Change & & & & \\
Ex-ante poverty - total & 33.48 & 33.48 & 33.48 & 33.48 \\
Ex-post poverty - total & 33.80 & 31.77 & 31.18 & 31.14 \\
Change & 0.32 & -1.72 & -2.30 & -2.34 \\
& & & & \\
Effects on inequality & & & & \\
Ex-ante Gini index - rural pop. & 0.339 & 0.339 & 0.339 & 0.339 \\
Ex-post Gini index - rural pop. & 0.340 & 0.341 & 0.334 & 0.332 \\
Change & 0.000 & 0.002 & -0.006 & -0.007 \\
Ex-ante Gini index - urban pop. & 0.419 & 0.419 & 0.419 & 0.419 \\
Ex-post Gini index - urban pop. & 0.489 & 0.396 & 0.419 & 0.425 \\
Change & 0.071 & -0.023 & 0.000 & 0.006 \\
Ex-ante Gini index - total pop. & 0.398 & 0.398 & 0.398 & 0.398 \\
Ex-post Gini index - total pop. & 0.431 & 0.405 & 0.396 & 0.394 \\
Change & 0.032 & 0.006 & -0.002 & -0.004 \\
\hline
\end{tabular}

Note: Levels and changes in poverty are measured in percent of relevant population: urban, rural or total. Levels and changes in inequality are measured in terms of the Gini coefficient, which varies from 0 to 1 , higher values indicating greater inequality.

Source: Author's calculations. 
Figure 1 The Gregory effect / Dutch disease / booming sector effect

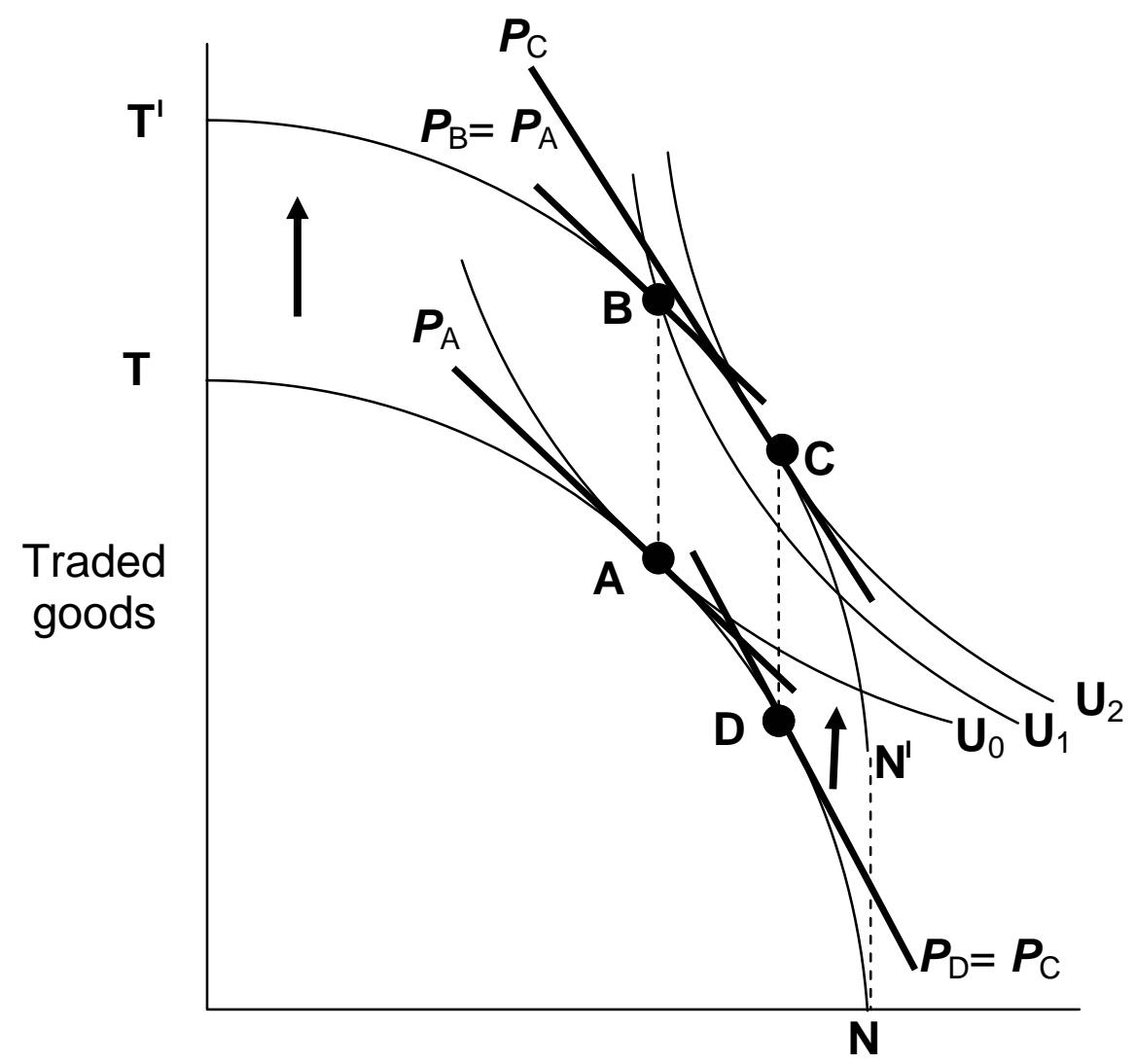

Non-traded goods 
Figure 2 Laos: GDP growth (\%) and CPI inflation (\%)

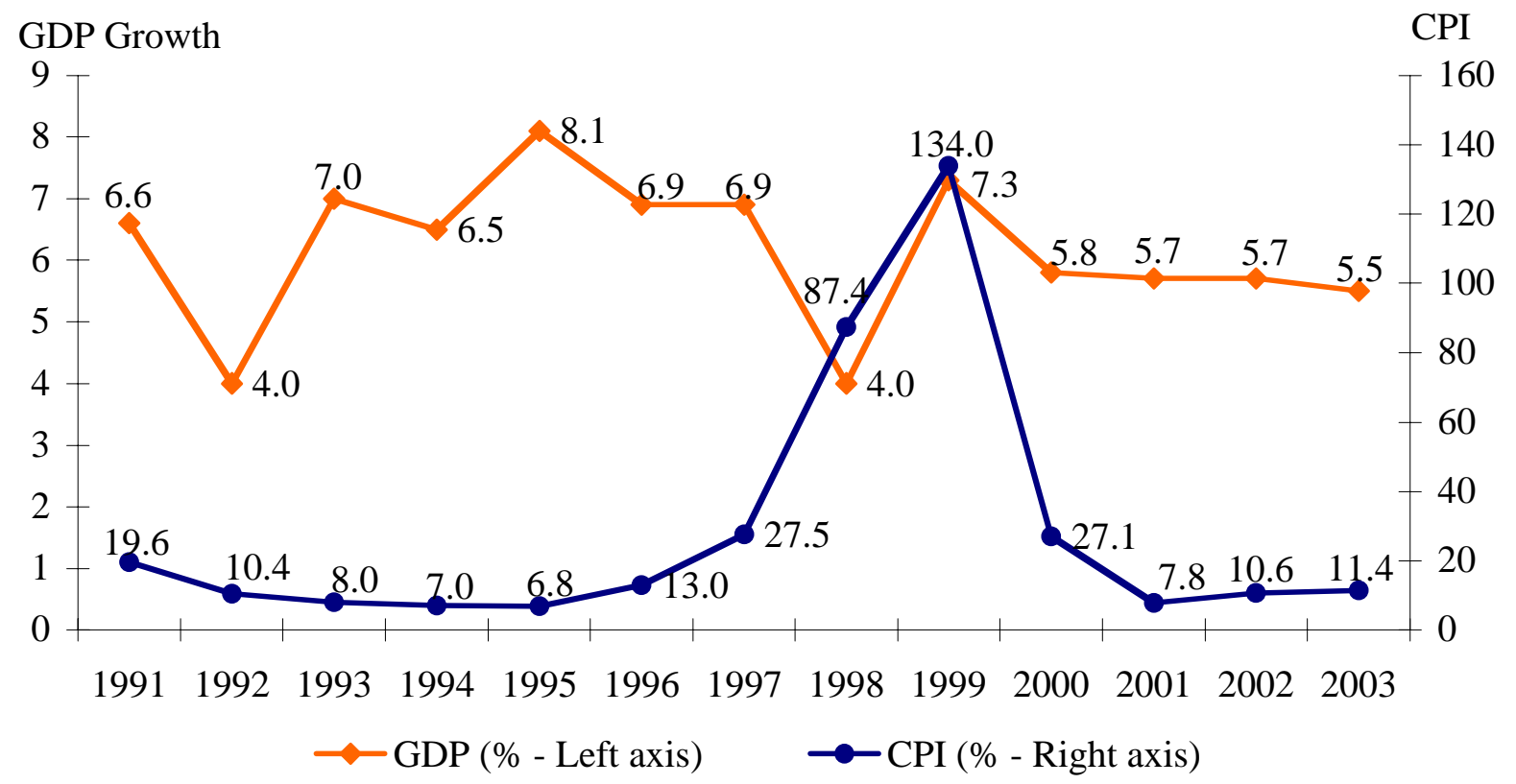

Source: Author's calculations using data from National Statistical Centre, Vientiane. 
Figure 3 Laos: Exchange Rates, 1988 to 2004

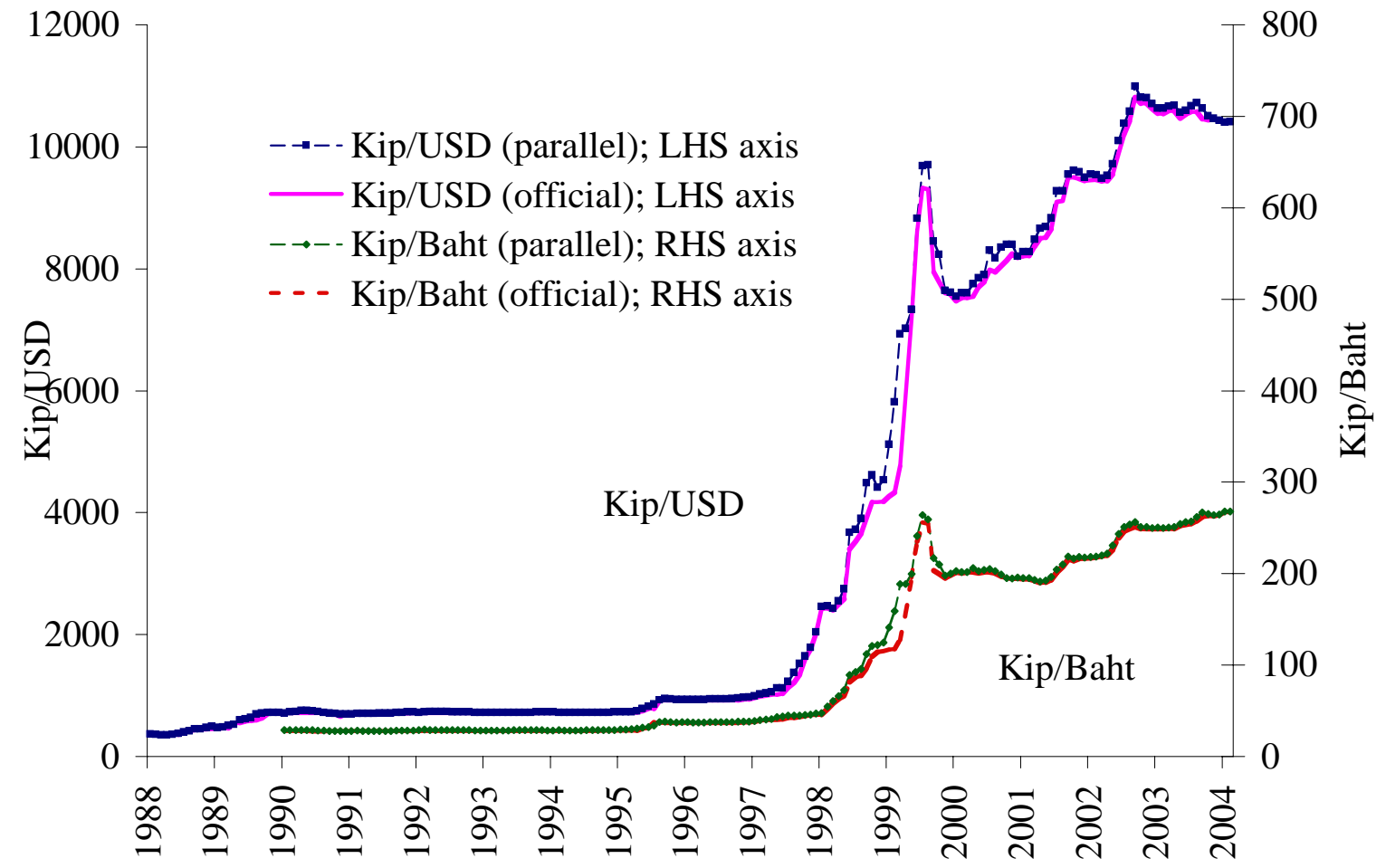

Source: Author's calculations using data from International Monetary Fund, International Financial Statistics, various issues. 
Figure 4 Laos: Current account deficit (\% of GDP)

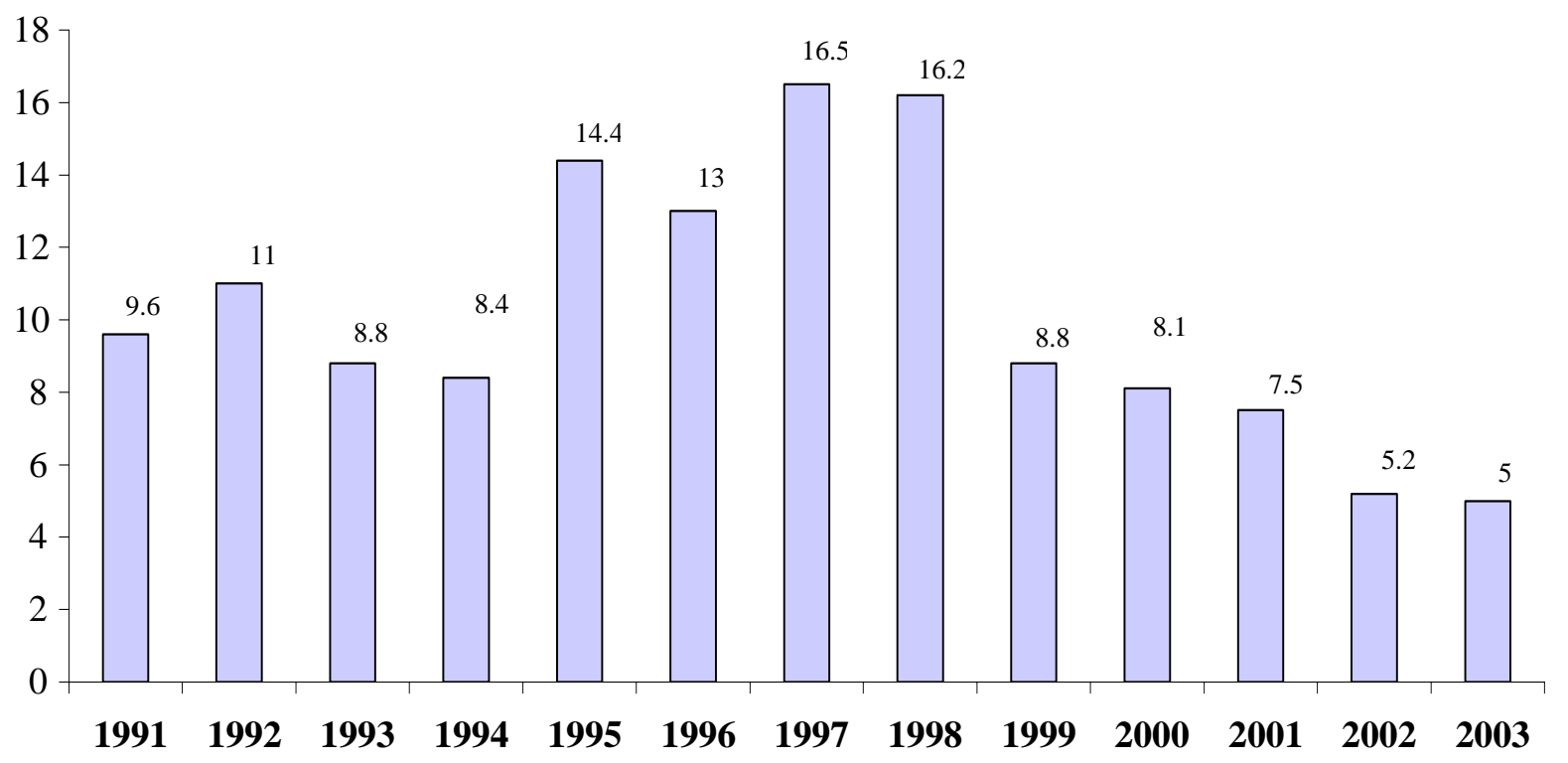

Source: Author's calculations using data from National Statistical Centre, Vientiane. 
Figure 5 Laos: Real exchange rates, annual averages, 1988 to 2003

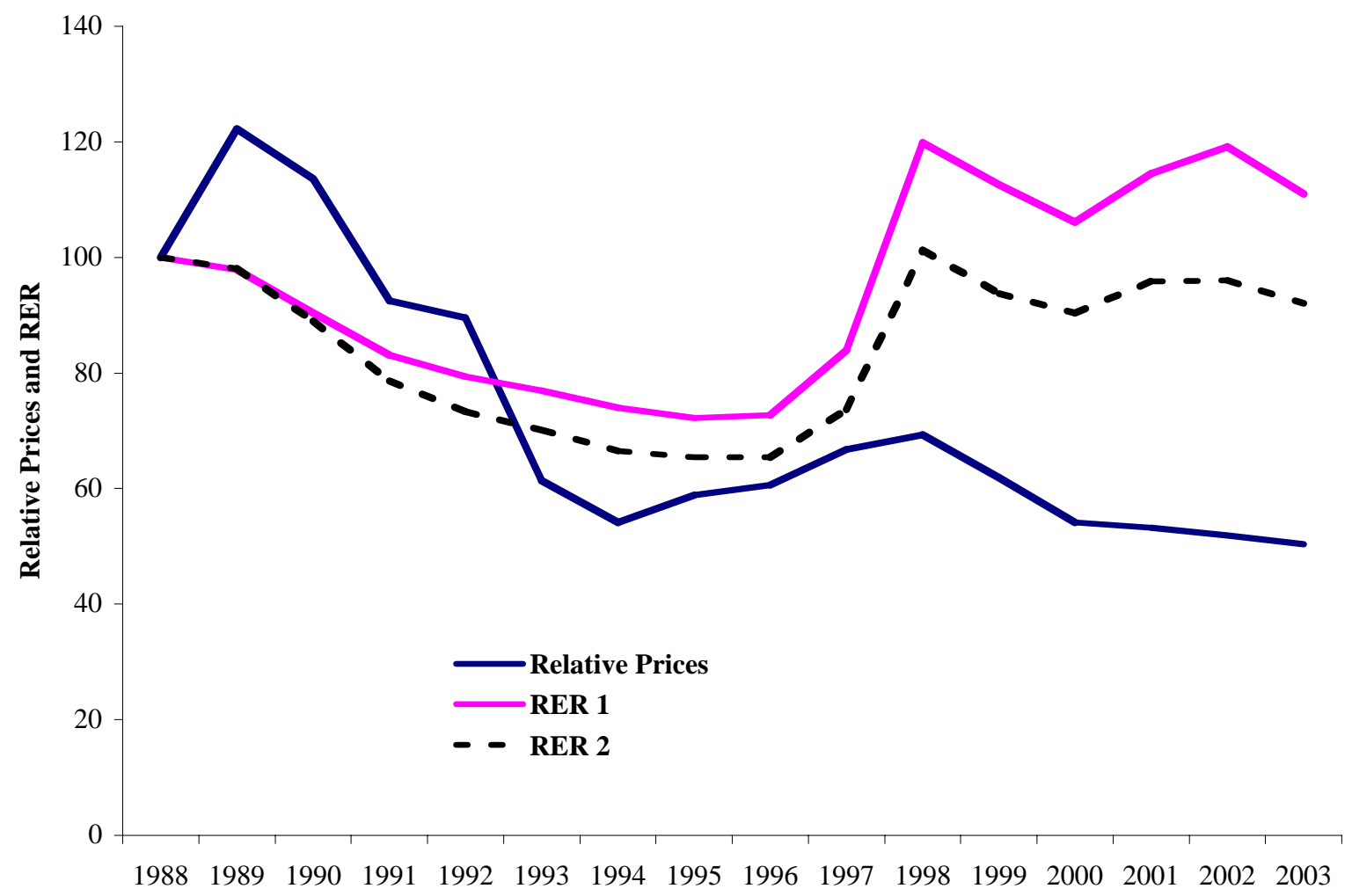

Note: 'Relative Prices' is the ratio of Food / Services consumer prices within Laos.

RER 1 is the exchange rate adjusted ratio of foreign consumer prices to Lao consumer prices. RER 2 is the exchange rate adjusted ratio of foreign producer prices to Lao consumer prices.

Source: Author's calculations using data from National Statistical Centre, Vientiane and IMF International Financial Statistics, various issues. 
Figure 6 Laos: Simulated effects on urban poverty (Case 1)

Urban

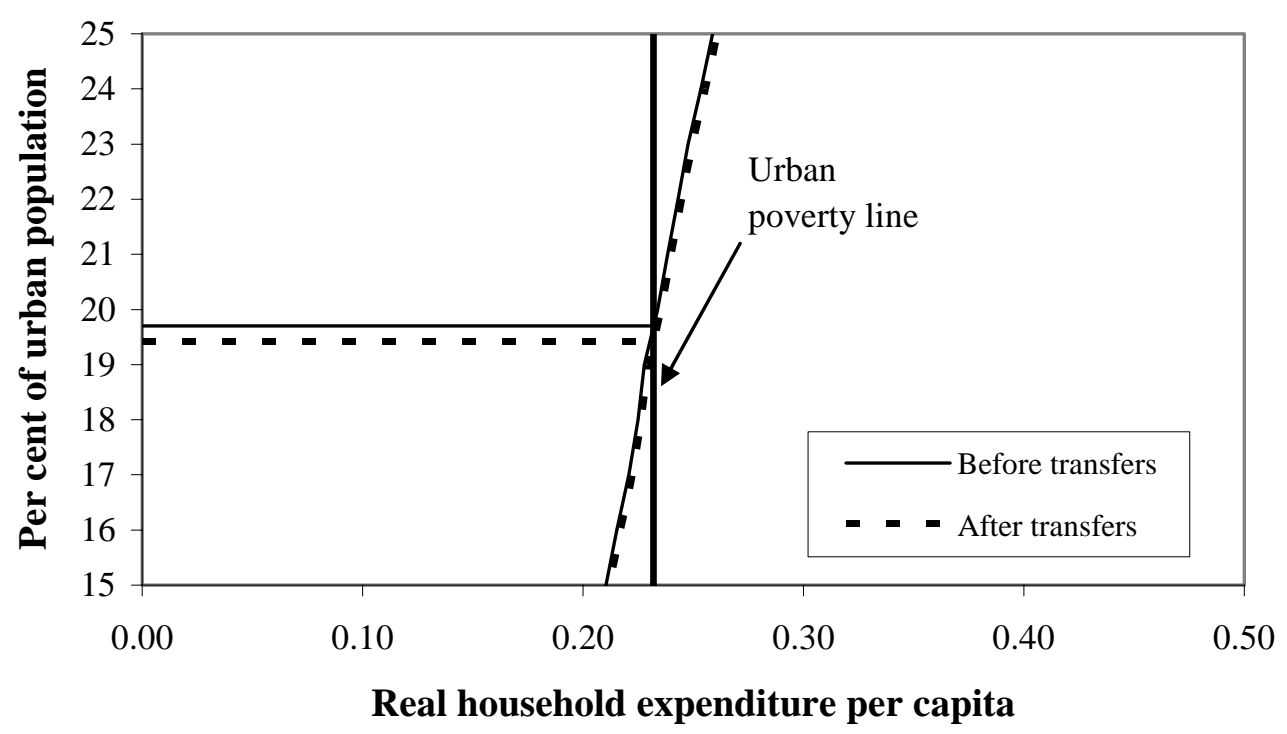

Note: The horizontal axis measures household expenditures in millions of Lao kip per year, 2002-03 prices. Source: Author’s calculations. 
Figure 7 Laos: Simulated effects on rural poverty (Case 1)

Rural

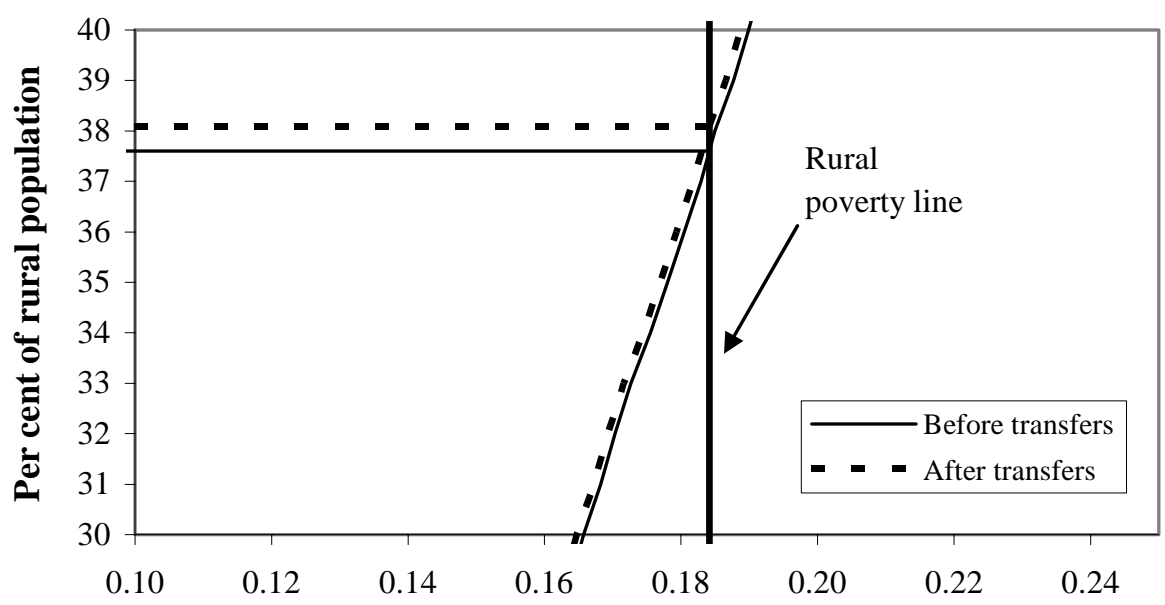

Real household expenditure per capita

Note: The horizontal axis measures household expenditures in millions of Lao kip per year, 2002-03 prices.

Source: Author's calculations. 